\title{
THE IMPACT OF GENDERED CHARACTERISRICS ON THE AUDIT PROCESS
}

\author{
Bassam Samir Mohamed Baroma \\ Lecturer-Accounting Department \\ Faculty of commerce \\ Tanta University
}


THE IMPACT OF GENDERED CHARACTERISRICS ON THE AUDIT PROCESS

\author{
Bassam Samir Mohamed Baroma \\ Lecturer-Accounting Department \\ Faculty of commerce \\ Tanta University
}

\begin{abstract}
Previous research on the gendering process in audit firms indicate that a "glass-ceiling" seem to exclude females from the highest positions (such as partnership) in audit firms and that audit firms are gendered through socialization, performance evaluation, recruitment policies, the use of symbols and the development of organizational roles.

Audit quality seems not only to be connected to what auditors do, but also to who the auditors are. Hence, auditor characteristics seem important. Abilities, skills and behaviour can come from and be developed by education and training, but also be a part of a person's personality.

This paper considers central aspects of auditing as a profession and point out the importance of auditors having certain (different) personal characteristics. Through the presentation of the audit process, characteristics required in the audit process and a distinction of female or male characteristics, this paper puts forward the proposition that the processes of auditing requires different characteristics of the auditors. These different characteristics can in turn be considered through a gender lens. Thus, the aim of this paper is to explore essential characteristics of auditors required in different parts of the audit process.

A questionnaire was sent to 1000 Egyptian auditors and the response rate was 16.9 per cent. The result indicates that the while the characteristic "analytical", which is classified as male, is considered the most essential characteristic, female characteristics are significantly more important in the planning stage and in the final review stage of the audit process.
\end{abstract}

Keywords: audit quality, audit process, characteristics, gender 


\section{INTRODUCTION}

Gendering is an ongoing process and auditors have been subject of it before they enter the audit firms (e.g. by the family or university attendance), and the experience of such processes continues while inside the firms (Anderson-Gough et al., 2005). According to Mills (1992:98) "people does not leave their cultural perceptions at the gates of organizations, they enter with them".

Previous research on the gendering process in audit firms (cf. e.g. Lehman, 1990, 1992; Kirkham, 1992; Kirkham \& Loft, 1993; Covaleski et al., 1998; Fogharty et al., 1998; Grey, 1998; Lowe et al., 2001; Anderson-Gough et al., 2005; Elg et al., 2006; Collin et al., 2007) indicate that a "glass-ceiling" seem to exclude women from the highest positions (such as partnership) in audit firms and that audit firms are gendered through socialization, performance evaluation, recruitment policies, the use of symbols and the development of organizational roles.

Since there seem to be a tendency of individuals to associate with others who think in similar ways (and since communication and relationship formation might be easier between individuals with shared common characteristics), customs and values are reproduced by organizational processes (Anderson-Gough et al., 2005). Homo-sociality structures the process of recruitment, mentoring and performance evaluation in routine and predictable ways. Male partners promote people with the same backgrounds and preferences as themselves and consequently there are very few women at the highest positions within audit firms (cf. Lowe et al., 2001, Anderson-Gough et al., 2005).

The recruitment process is an important aspect of a profession (such as auditing). While gendering processes seem to be something that is going on almost "behind closed doors" in audit firms, the recruitment process seem more gender balanced. When it comes to new entrants to the audit industry there seem to be just as many women as men. Psychometric testing, used to measure for example abilities, attitudes, knowledge and personality traits, is one of the assessments in the recruitment process (cf. Armstrong, 2006). The fact that different kinds of "personality tests" are used in the recruitment process indicates that personal characteristics are of importance. 
In this paper the researcher considers central aspects of auditing as a profession and point out the importance of auditors having certain (different) personal characteristics. The characteristics will further be considered through a gender lens, making it possible to identify whether specific characteristics in the audit process are of male or female character. Thus, the aim of this paper is to explore essential characteristics of auditors required in different parts of the audit process.

\section{THE AUDIT PROFESSION}

There probably is not an ideal-type of profession, but there are certain general attributes linked to and combined by a profession that seems to be fairly agreed upon (cf. Larson. 1977; Brante, 1988): applied knowledge and techniques, training, service orientation, ethics, autonomy and prestige. According to Magali Sarfatti Larson (1977) members of a profession "share a relatively permanent affiliation, an identity, personal commitment, specific interests, and general loyalties". Special knowledge and skills are a part a profession (cf. Larsson, 1977; Brante, 1988).

Auditing is a profession (cf. e.g. Carr-Saunders \& Wilson, 1933; Flint, 1988) and according to R. K. Mautz and Hussein A. Sharaf (1961) its method consists of an attitude (auditors adopts a position of impartiality, have a restricted interest and inquire matters primarily requested to make judgement which are based on reasonably available evidence) and a procedure (auditing deals with both problems of fact and problems of value judgement). Environmental conditions (Brody et al., 1998) along with personal, social and organizational factors "influence judgement and decisions that are reflected in behaviour" (ICAEW, 2007:2).

The professional audit firm environment is characterised of socialization. Unwritten rules and customs are important. Individuals who do not behave in a manner that correspond with the rules, customs and objectives of the firm are identified and might be told to leave the firm (e.g. Akarlof, 1970; Grey, 1998). Firm characteristics include different corporate cultures which effects and attitudes towards risk (e.g. Dirsmith \& Haskins, 1991), image-building, how to negotiate with clients and how to solve technical disputes and client objectives (e.g., 1992b). This indicates that there is a pressure on individual auditors not only to perform but also to adapt certain appropriate behaviour.

\section{THE AUDIT PROCESS}

According to David Flint (1988:101) "the audit process is a systematic examination of the matters which are the subject of audit to find out the relevant facts to inform the mind of the auditors, and from which the auditor may deduce conclusions and exercise judgement to arrive at an opinion or report". 
It should be pointed out that the examination carried out is dependent on particular circumstances. However, one could assume that there are certain auditor characteristics that are important in a certain (or all) part(s) in the audit process.

The audit process probably does not look the same and do not have the same content all over the world. Yet the overall pattern is most likely the same and in most cases it more or less consists of certain central procedures. Flint (1988:102) identifies three stages of the audit process (written in italics in the list below) made up by seven elements ${ }^{1}$. The audit process has been divided into the following 3 stages including 12 parts $^{2}$ :

The planning stage - obtaining, evaluating and drawing conclusions from the evidence

1. Client acceptance - determine whether the auditor meet independence requirements regarding the client

2. Collect information about and gain understanding of the client, its activities, its environment and its circumstances

3. Plan the audit (enquiry of relevant personal, etc)

4. Work out an audit plan and examination plan

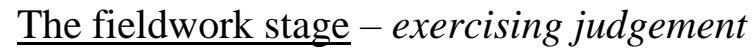

5. Planning materiality (assess audit risk and set materiality limits)

6. Evaluate and test internal controls (identify strengths and weaknesses of internal controls and ascertain whether controls are functioning properly)

7. Substantive testing (test transactions and account balances)

8. Examination of the Annual Report and the bookkeeping

9. Examination of the management's administration of the company ("management audit")

The final review stage - reporting

10. Internal reports (to those charged with governance of the entity)

11. External reports (to shareholders and other parties external to the entity)

12. Documentation

\footnotetext{
${ }^{1}$ For the complete list we refer to Flint, 1988:102

${ }^{2}$ The stages and parts are based on and influenced by Flint (1988), but updated with some more recent references such as auditing textbooks (Wolf, 1997; Hayes, Dassen, Schilder \& Wallage, 2005; Porter, Simon \& Hatherly, 2006), material from the profession (FAR, 2006) and previous studies dividing the audit process in different stages (Cho \& Lew, 2000).
} 


\section{IMPORTANT AUDITOR CHARACTERISTICS}

The selection (recruitment) of certain individuals to an audit firm can be seen as the first stage of the socialization process (cf. Anderson-Gough, Grey \& Robson, 1998; Covaleski et al., 1998; Dirsmith \& Covaleski, 1985). With such selection process a firm "is attempting to introduce types of skills and behaviours that are seen as desirable" (Anderson-Gough, Grey \& Robson, 1998:56). According to Fiona Anderson-Gough, Christopher Grey \& Keith Robson (1998) to technical and social competence are important. It have thereby also been indicated that academic ability (e.g., grades) is not the only focus in the selection process (cf. AndersonGough, Grey \& Robson, 1998; Halling, 2007). In the discussion paper "Promoting Audit Quality" the Financial Reporting Council (2006:27) states that "audit is a discipline that relies on competent individuals exercising such qualities as integrity, objectivity, rigour, scepticism, perseverance and robustness to enable them to make reliable judgements" and that "the skills of audit partners and staff lie at the heart of an audit form's ability to undertake a high quality audit". The skills base includes "technical skills, business knowledge and experience, combined with innate judgement skills" (FRC, 2007:27). The report "Reporting with integrity" issued by the Institute for Charteread Accoutants in Enland and Wales focus on integrity and states that it is "essentially a personal quality" (ICAEW, 2007:2) related to certain behavioural characteristics such as e.g., being honest, truthful, fair and complying with laws. Abilities, skills and behaviour can come from and be developed by education and training, but also be a part of a person's personality.

International Education Standards (e.g., IES 3, IES 6 \& IES 8) issued by the International Accounting Education Standards Board (IAESB) outlines skills grouped into the following areas: (i) intellectual skills, (ii) technical and functional skills, (iii) personal skills, (iv) interpersonal and communication skills and (v) organizational and business management skills. This indicates that personal characteristics are considered of high importance.

Large audit firms are hierarchical and auditors work in teams. An audit team for an individual engagement often reflects the hierarchal structure in the firm - certain tasks are performed by relatively inexperienced auditors and vice versa. (FRC, 2007) The fact that auditors work in teams indicate that resources can be allocated and different skills and characteristics can be combined to effectively conduct high quality audits.

Audit quality seems not only to be connected to what auditors do, but also to who the auditors are. Hence, auditor characteristics seem important. In this paper we reflect upon personal characteristics per se and not upon how they can be "acquired" and developed. 


\section{DEFINITIONS AND CHARACTERISTICS}

A student thesis (Duggal Sharma \& Schischke, 2007) have through interviewing two approved public accountants from two different Swedish auditing firms come up with 16 characteristics held as of highest importance for the auditing process. The process of coming to this result is based on structured interviews, one each with the two auditors (lasting about 45-60 minutes). The auditors were asked to, for the different steps in an audit review, state essential characteristics of the auditor. This paper applies their distinction of important characteristics in the audit process and the characteristics are further depicted in the table below and presented in alphabetical order.

Table 1 - Important characteristics in the auditing process and their definitions

\begin{tabular}{|c|c|}
\hline Characteristic: & Defined as: \\
\hline 1 Accurate & to be thorough and orderly \\
\hline 2 Analytical & an eager to explore and investigate \\
\hline 3 Attentive & to be watchful for what's happening \\
\hline 4 Careful & to care, be prudent \\
\hline 5 Competent to make fast decisions & to fast be able to decide and make decisions \\
\hline 6 Co-operative & to work together with others and teamwork \\
\hline $7 \quad$ Law-abiding & to follow laws, norms and practise \\
\hline 8 Linguistic & to be able to express yourself in speech and in written form \\
\hline 9 Mathematical & $\begin{array}{l}\text { to have an understanding of figures and how things add together, } \\
\text { spatial ability }\end{array}$ \\
\hline 10 Networking & to be able to create large networks, to be social \\
\hline 11 Objective & straightforward, to be realistic and sincere \\
\hline 12 Organizing ability & to be able to plan and structure \\
\hline 13 Self-confidence & to have confidence in your own ability \\
\hline 14 Simultaneous ability & $\begin{array}{l}\text { the ability to do many different things at the same time, to be } \\
\text { flexible }\end{array}$ \\
\hline 15 Target-oriented & that you are determined and have a clear image of the goal \\
\hline 16 Willingness to assume risk & to dare to bet even though the outcome is unknown \\
\hline
\end{tabular}

\section{A GENDER LENS ON THE CHARACTERISTICS}

The different characteristics that above were identified as of importance in the audit process could be considered just as characteristics of importance. Or, the characteristics could be considered through one, or many, lenses, of which one could be class, another education and a third age. The paper presents a fourth lens, that of gender. Gender has the latest years been a frequent topic in the business press including discussions such as; the glass ceiling hindering women from reaching the highest positions in organisations (Morrison \& Glinow, 1990; Dalton \&Kesner, 1993; Arfken, Bellar \& Helms, 2004); glass floor restricting women advancement also at lower levels in the organisation (Tharenou, 2001); similarity-attraction 
paradigm where equals prefer to recruit equals (Tsui \& O'Reilly, 1989); compensation in relation to gender (Bertrand \& Hallock, 2001; Mohan \& Ruggiero, 2003; Bowlin \& Renner, 2007); the issue of allocating women to the board of directors by quotas (Huse, 2007). Due to its public interest the characteristics required in the auditing process will be considered through a gender lens. The advantage with this approach is that if offers more than just consider the characteristics in singular, and adds to the gender notice in the audit process.

The gender lens on the characteristics implies that the above identified characteristics need to be classified in accordance of being more of women or men characteristics, which can be considered as rather controversial. However, there is support for a notion of differences between men and women, some are based on biological differences saying that we differ already from birth, and some are based on the social construction idea where men and women are shaped differently according to societal and organisational context in which we develop (Kanter, 1977; Acker, 1990; Ely, 1995; Nordahl, 1995; Leander, 2004). The researcher would argue that the gender is created as a mix of biological and societal influences. The 16 characteristics are therefore further discussed in terms of being more of female or male characteristic (table 2). The classification of the characteristics' gender is supported by literature and by own arguments.

Table 2 - Classification and arguments for female and male characteristics

\begin{tabular}{|l|l|}
\hline $\begin{array}{l}\text { Characteristics } \\
\text { classified as female }\end{array}$ & \multicolumn{1}{|c|}{ Arguments and references } \\
\hline F1. Accurate & $\begin{array}{l}\text { Women in organisations tend to have functions of administration and } \\
\text { organisation (Plowman, 2004) and women have been claimed to be better at } \\
\text { documentation preparation (Dalton \& Kesner, 1993). This could imply that } \\
\text { women are more talented for tasks demanding thoroughness. This would } \\
\text { indicate that women, compared to men, have more of an accurate character. }\end{array}$ \\
\hline F2. Attentive & $\begin{array}{l}\text { Women are better at understanding social hints and to notice differences in tone and intensity, } \\
\text { women are also stated to be better at understanding what people mean although they don't say } \\
\text { anything (Shields, 2007; Moir \& Jessel, 1989). Hayes, Allinson \& Armstrong (2004) discusses } \\
\text { that men managers are insensitive which could be complemented by women managers who } \\
\text { instead are intuitive. This would indicate that women, compared to men, have more of an attentive } \\
\text { character. }\end{array}$ \\
\hline $\begin{array}{l}\text { Favies \& Thomas (2002) distinguish between masculinity and femininity where } \\
\text { femininity is referred to emotional, empathetic, caring and supportive and more } \\
\text { prominent among women. Studies on babies have found that whereas boys are } \\
\text { more intense in their games, girls tend to be more careful (Morris, 1998). This } \\
\text { would indicate that women, compared to men, have more of a careful character. }\end{array}$ \\
\hline F4. Co-operative & $\begin{array}{l}\text { Authors argue that leadership styles preferred by women relate to female values } \\
\text { developed through socialization processes that include building relationships, } \\
\text { communication, consensus building, power as influence, and working together for a } \\
\text { common purpose (Oshagbemi \& Gill, 2003; Rigg \& Sparrow, 1994). They are also } \\
\text { stated to adopt democratic and participative leadership styles (Trinidad \& Normore, } \\
\text { 2005). This would indicate that women, compared to men, have more of a co-operative } \\
\text { character. }\end{array}$ \\
\hline
\end{tabular}




\begin{tabular}{|c|c|}
\hline F5. Law-abiding & $\begin{array}{l}\text { Valentine and Rittensburg (2007) claims that it from studies can be concluded } \\
\text { that women leaders, compared to men leaders, are better at ethical judgements. } \\
\text { Reasons why women have higher moral concerning "doing the right thing", } \\
\text { could be that women focuses on personal and relational aspects in their } \\
\text { judgement of ethical problem. This would indicate that women, compared to } \\
\text { men, have more of a law-abiding character. }\end{array}$ \\
\hline F6. Linguistic & $\begin{array}{l}\text { Daily \& Dalton (2003:9) suggest that women in boards "... provide unique } \\
\text { perspectives, experiences, and work styles..." and that "Women's } \\
\text { communication styles tend to be more participative and process-oriented." This } \\
\text { would indicate that women, compared to men, have more of a linguistic } \\
\text { character. }\end{array}$ \\
\hline $\begin{array}{l}\text { F7. Organizing } \\
\text { ability }\end{array}$ & $\begin{array}{l}\text { Plowman, (2004) claims that women are still more caring and nurturing in their } \\
\text { roles in organisations, and that they tend to perform functions of administration } \\
\text { and organisation. This could imply that women are better at this, or at least, } \\
\text { perform these roles more often than men. An interview in the study by Dalton \& } \\
\text { Kesner (1993) has claimed that women are better at documentation preparation. } \\
\text { This would indicate that women, compared to men, have more of an organizing } \\
\text { ability. }\end{array}$ \\
\hline $\begin{array}{l}\text { F8. Simultaneous } \\
\text { ability }\end{array}$ & $\begin{array}{l}\text { Pease \& Pease (2006) have shown that the ability for simultaneous action is } \\
\text { more common among women than men, the explanation lies in construction of } \\
\text { our brains where women have more connection between the two brain halves. } \\
\text { This would indicate that women, compared to men, have more of a simultaneous } \\
\text { ability. }\end{array}$ \\
\hline $\begin{array}{l}\text { Characteristics } \\
\text { classified as male }\end{array}$ & Arguments and references \\
\hline M1. Analytical & $\begin{array}{l}\text { Bem (1974) argues that the masculine role is characterised by an analytical and } \\
\text { individualistic behaviour. Also Hayes, Allinson \& Armstrong (2004) describe } \\
\text { men as being more analytically oriented than women. This would indicate that } \\
\text { men, compared to women, have more of an analytical character. }\end{array}$ \\
\hline $\begin{array}{l}\text { M2. Competent to } \\
\text { make fast decisions }\end{array}$ & $\begin{array}{l}\text { Women were above discussed to have a stronger organizing ability, men on the } \\
\text { other hand, have been argued to be more decision-oriented (Plowman, 2004) } \\
\text { which could indicate that men, compared to women, have more of a decision- } \\
\text { making character. }\end{array}$ \\
\hline M3. Mathematical & $\begin{array}{l}\text { Men have been found to score higher than women on mathematical tests } \\
\text { (Stainton Rogers \& Stainton Rogers, 2002). Men are also said to have a better } \\
\text { understanding of spatial issues (Moir \& Jessel, 1989). This could indicate that } \\
\text { men, compared to women, have more of a mathematical character. }\end{array}$ \\
\hline M4. Networking & $\begin{array}{l}\text { Research on the advantages of networking in relation to job searching has indicated that } \\
\text { women and men use informal networks for a position to the same extent (Marsden \& } \\
\text { Campbell, 1990; Moore, 1990). Men have also been argued to be more comfortable in } \\
\text { socialisation events (Moir \& Jessel, 1989). This would indicate that men, compared to } \\
\text { women, have more of a networking character. }\end{array}$ \\
\hline M5. Objective & $\begin{array}{l}\text { "The concept of gender role is situationally constructed in organizations, and } \\
\text { based on: masculinity involving aggression, independence, objectivity, logic, } \\
\text { analysis, and decision, and; femininity involving emotions, sensitivity, } \\
\text { expressiveness, and intuition." (Trinidad \& Normore, 2005:576). Masculinity } \\
\text { has also been stated to be non-emotional, i.e. rational, logical and reasoned } \\
\text { (Davies \& Thomas, 2002). This could indicate that men, compared to women, } \\
\text { have more of an objective character. }\end{array}$ \\
\hline M6. Self-confidence & $\begin{array}{l}\text { In the entrepreneurship literature women have been found to, compared to men, } \\
\text { less often perceive themselves as entrepreneurs and women have been claimed } \\
\text { to, compared to men, underestimate their performance (Verhelu, Uhlander \& } \\
\text { Thurik, 2005). The male hormone of testosterone is said to strengthen } \\
\text { characteristics such as self-confidence (Moir \& Jessel, 1989). This would } \\
\text { indicate that men, compared to women have more of a self-confident character. }\end{array}$ \\
\hline
\end{tabular}




\begin{tabular}{|l|l|}
\hline M7. Target-oriented & $\begin{array}{l}\text { Masculinity has been associated with task-oriented leadership styles, and } \\
\text { femininity with relationship-oriented leadership styles (Rigg \& Sparrow, 1994; } \\
\text { Oshagbemi \& Gill, 2003). Pounder \& Coleman (2002) claim that barriers for } \\
\text { women aspiring for leadership positions is the nurturing and caring role often } \\
\text { attached to women which make them more occupied with supportive roles, in } \\
\text { contrast to men who are occupied with leadership roles. Being task-orientation } \\
\text { and focused on leadership could imply that men, compared to women, have } \\
\text { more of a target-oriented character. }\end{array}$ \\
\hline $\begin{array}{l}\text { M8. Willingness to } \\
\text { assume risk }\end{array}$ & $\begin{array}{l}\text { Literature indicates that women are more risk averse than men, e.g. Powell and } \\
\text { Ansic (1997), Watson \& Robinson (2003), Hudgens \& Fatkins (1985), Barber \& } \\
\text { Odean (2001), Sexton and Bowman-Upton (1990). Women compared to men } \\
\text { have also been found to be more careful when they bind resources (Watson \& } \\
\text { Robinson, 2003), see for example Watson, 2002:92 "females, on average, will } \\
\text { devote fewer resources to their business ventures, thereby reducing their } \\
\text { exposure (risk) should things go wrong". This would indicate that men, } \\
\text { compared to women, have more of a risk-willingness character. }\end{array}$ \\
\hline
\end{tabular}

Through the presentation of the audit process, characteristics required in the audit process and a distinction of female or male characteristics, this paper puts forward the proposition that the processes of auditing requires different characteristics of the auditors. These different characteristics can in turn be considered through a gender lens.

\section{Methodology}

\subsection{Sample}

The study's empirical object is Egyptian accountants and method for collecting data has been a web-based questionnaire. The accountants (names and e-mail addresses) were identified through the webpage, which is the professional organisation for authorized public accountants, approved public accountants and other highly qualified professionals in the accountancy sector in Egypt. The identified chartered accountants amount to 1000 of which 308 are women. The low share of women can be explained with an overall lower share of Egyptian chartered accountants. The identified accounts were sent an e-mail including a brief introduction letter explaining the purpose of the study, added with a link to the web-site with the questionnaire. From the 1000 sent e-mails, 169 accountants participated and filled out the questionnaire which results in a response rate of 16.9 per cent. From the 169 responses, 117 are men and 52 are women. The respondents' sexes, mean age and experience in business are showed in table 3 below and show that the majority of the respondents are men and that the men also are slightly older and have more experience from the business.

Table 3 - Respondents with their age and experience in business

\begin{tabular}{|l|l|l|l|}
\hline & & age (mean) & experience (mean) \\
\hline All respondents & $\mathbf{1 6 9}$ & $\mathbf{4 8 , 2 2}$ & $\mathbf{2 1 , 1 8}$ \\
\hline Men & $69,20 \%$ & 49,91 & 23,06 \\
\hline Women & $30,80 \%$ & 44,57 & 17,15 \\
\hline
\end{tabular}




\subsection{Operationalization and measures}

The auditing process has been divided into 3 stages consisting of 12 parts in total. The researcher wants the respondents to mark the three most essential characteristics. Each subcategory and its characteristics refer to one question, which gives us in total 12 questions referring to the 12 parts of the auditing process and essential characteristics. To make sure that the parts of the audit process were understood by the respondents, a brief explanation of each subcategory was presented.

After the brief introduction of each process, a list of 17 characteristics was presented (16 closed alternatives (see table 1), and 1 open alternative where the respondents could state a characteristic of their own choice. The 16 characteristics were slightly more elaborated than just one word and defined and explained as in table 1.

The study does not want the respondents to place the characteristics in order of preference, but just to mark the three most essential. The reason for this is mainly that it could be difficult to among 16 alternatives choose one characteristic to be superior another. They were instead asked to state three that they found to be the most essentials, but no need to put them in any specific order.

To be able to test the reliability of the data the questionnaire also included three closed questions asking the respondents to state their: sex - the three characteristics marked as essential could be argued to differ depending on the sex of respondents; age - also the age of the respondents could influence what characteristics you hold as main important; and finally experience (number of years working as an auditor) since a well-experienced accountants could have other preferences for important characteristics than a less experienced accountants.

\section{ANALYSIS \\ 8.1. Reliability tests}

To test for differences among the respondent, the researcher has performed three reliabilitytests aiming at detecting patterns concerning the respondents' sex, age and experience. Sex was tested with Chi Square tests and resulted in no significant differences at the $5 \%$ level. Age and Experience were tested with ANOVA tests and gave one significant result (0.038) for Age and Process 7 - indicating that the younger the respondent the higher the share of female characteristics and vice versa. These tests would indicate a high reliability in the data set. 


\subsection{Descriptive statistics}

Table 4 includes all 16 characteristics and the alternative "other" and the total score for each characteristic. The characteristic "Analytical" has the highest score (810) which imply that most respondents found this characteristic important in the audit process. "Willingness to assume risk" has the lowest score (13) which imply that very few respondents found this characteristic important in the audit process. The table also shows that female (in italics) and male characteristics are widely spread.

Table 4 - Descriptive statistics

\begin{tabular}{|l|l|r|}
\hline \multicolumn{2}{|c|}{ Characteristics } & "Score" \\
\hline M1 & Analytical & 810 \\
\hline F1 & Accurate & 637 \\
\hline M5 & Objective & 543 \\
\hline F2 & Attentive & 503 \\
\hline F5 & Law-abiding & 404 \\
\hline F7 & Organizing ability & 340 \\
\hline F6 & Linguistic & 334 \\
\hline M7 & Target-oriented & 326 \\
\hline M3 & Mathematical & 313 \\
\hline F4 & Co-operative & 192 \\
\hline F3 & Careful & 184 \\
\hline M6 & Self-confidence & 93 \\
\hline F8 & Simultaneous ability & 65 \\
\hline M2 & Competent to make fast decisions & 57 \\
\hline M4 & Networking & 48 \\
\hline & "Other" & 26 \\
\hline M8 & Willingness to assume risk & 13 \\
\hline
\end{tabular}

\section{Binominal tests of characteristics in audit processes}

This part of the analysis is structured according to the three stages (The planning stage, the fieldwork stage and the final review stage) and includes 12 parts of the audit process.

\subsection{The planning stage}

This stage includes five processes and figure 1 shows the eight characteristics that received the highest score for each of these processes. In Process 1 the female characteristic "Lawabiding" got $62.7 \%$, this means that $62.7 \%$ of the respondents marked "Law-abiding" as one of the three most important characteristics in Process 1. A Binominal test for Process 1 shows that female characteristics is considered significantly (0.000) more important than male characteristics. In Process 2 the male characteristic "Analytical" has got the highest score (79.9\% marked this characteristic as important) but the Binominal test show no significant 
(0.789) overall result for this process. In Process 3 the female characteristic "Organizing ability" is considered most important (65.7\%) and according to the Binominal test female characteristics is considered significantly (0.000) most important in this process. In Process 4 and 5 the male characteristic "Analytical" receive the highest scores $(60.9 \%$ and $71.9 \%$ respectively is marking "Analytical" as important). Binominal tests show that in both Process 4 and 5 male characteristics are considered more important than female characteristics $(0.061$ and 0.000 respectively).

The overall result for The planning stage is that even though the male characteristic "Analytical" scores highest, female characteristics such as "Attentive", "Organizing ability" and "Accurate" adds to the aggregated result for The planning stage indicating that female characteristics are considered significantly (0.000) more important than male.

\subsection{The fieldwork stage}

This stage includes four processes and figure 1 shows the eight characteristics that received the highest score for each process. In Process 6 the male characteristic "Analytical" got the highest score (48.5\%). Binominal tests for Process 6 and Process 8 show no significant $(0.190$ and 1.000 respectively) overall results for these processes. In Process 7 the male characteristic "Analytical" has got the highest score (50.9\% marked this characteristic as important) and the Binominal test shows that male characteristics are significantly (0.001) more important in this process. In Process 9 the female characteristic "Attentive" is considered most important $(34.3 \%)$ and according to the Binominal test female characteristics is considered significantly (0.000) most important in this process.

The overall result for the fieldwork stage is that the male characteristic "Analytical" scores highest, but overall, this stage can be classified neither as female nor male (0.385).

\subsection{The final review stage}

This stage includes only three processes and figure 1 shows the eight characteristics that received the highest score for each of these processes. In Process 10 the male characteristic "Objective" got 75.1\%. The binominal test for Process 10 shows no significance $(0.463)$ concerning female or male characteristics. In Process 11 the female characteristic "Lawabiding" has got the highest score (70.6\% marked this characteristic as important) and the Binominal test also shows that female characteristics is considered significantly $(0.000)$ most important in this process. In Process 12 the female characteristic "Accurate" receive the highest scores $(67.5 \%)$. Binominal tests show that in Process 12 female characteristics are considered more important than male characteristics (0.026). 
The overall result for The final review stage is that even though the male characteristic "Objective" scores highest, female characteristics such as "Accurate", "Linguistic" and "Lawabiding" adds to the aggregated result for The final review stage indicating that female characteristics are considered significantly (0.000) more important than male. 

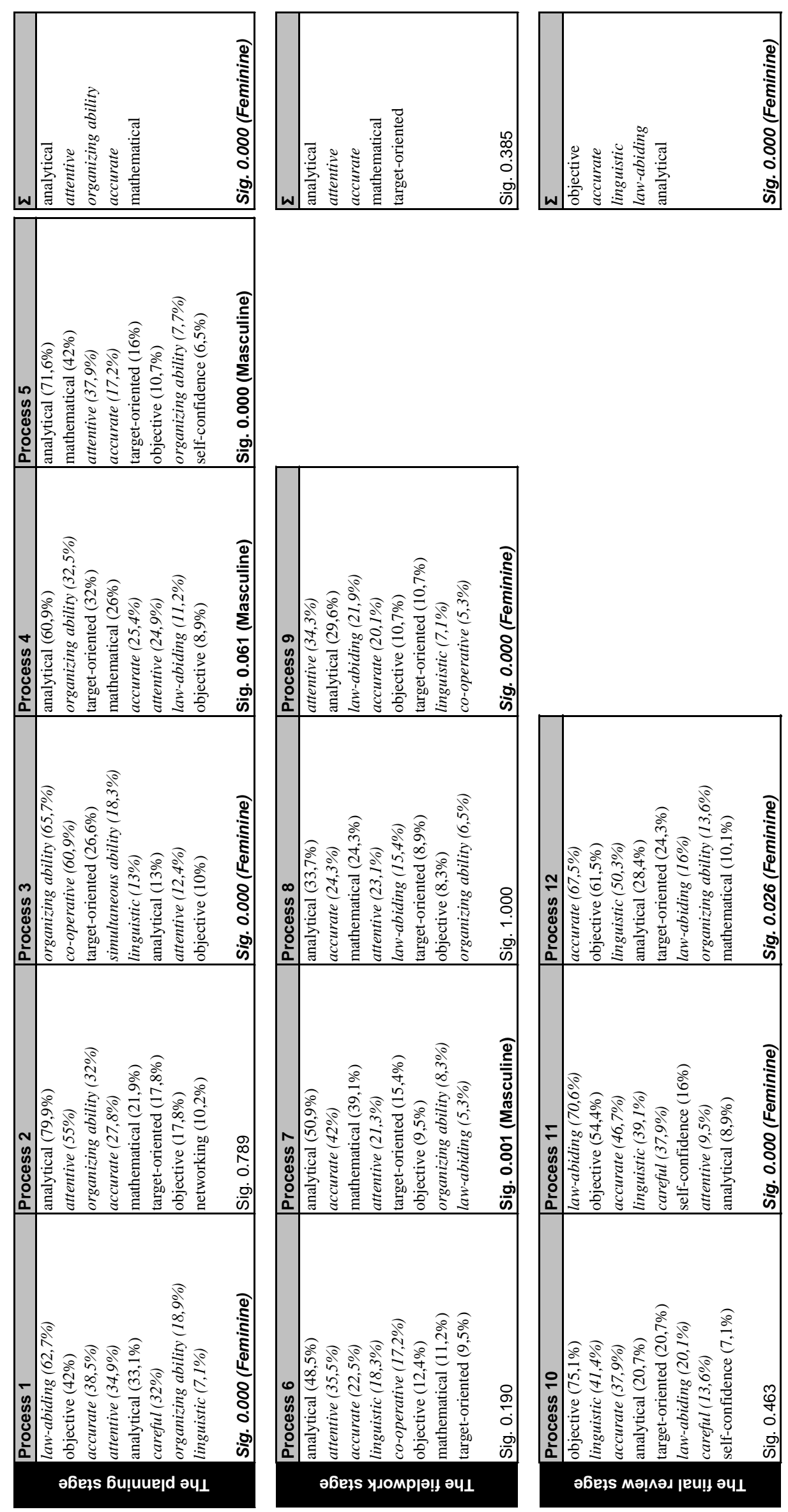

Figure 1 - Binominal tests 


\section{CONCLUSION AND DISCUSSION}

The aim of this paper has been to explore essential characteristics of auditors required in different parts of the audit process. Through a distinction of three stages (including 5, 4 and 3 processes), the study could identify two stages which, to a significant degree, were considered to include more of female characteristics than male. For one stage, the study could find no significant differences due to female or male characteristics, i.e., male and female characteristics were considered equally important.

Before going further into the results of this paper, the shortcomings of this study should be mentioned. One of them concerns the issue of classifying 16 characteristics as being of female or male characteristics, and the arguments pro and con could be extensively enlarged. This is however a first attempt to see whether it is possible to see audit characteristics with a gender perspective. Another shortcoming of the paper is that it views females as one homogenous group and males as another homogenous group, which allows no difference within these groups. A further development would be to consider differences within the gender group.

A shortcoming of the method applied concerns the way of collecting data. The study has used a survey to get respondents' opinions of important characteristics in the audit process. This implies that the respondents need to make their own interpretation of, for example, the characteristic "attentive", which could result in that the respondents put the own meanings to the words. The intention has however been to reduce this problem by including brief explanations of the characteristics.

In spite of this, the paper would argue that it has reached interesting results that are worth considering, both for the aggregated level of audit stages, but also for the specific audit processes. An important and interesting finding is that "important characteristic", i.e., characteristic scoring high, differs with process, and even more, it differs with stage. In the planning and the fieldwork stage the characteristic of analytical and attentive appear as important, whereas in the final review stage the characteristic of objective is the most important. Also the characteristic of linguistic appears as being of higher importance in this stage than the others. This would indicate that different individuals with different characteristics are needed to fulfil all the processes an auditor has to work with.

Another implication that can be drawn is the issue of team-composition. Auditors tend to work in teams, and being aware of different characteristics needed in the group might add to 
its working climate and performance. One could, for example, think of a composition including both people of analytical but also of attentive and accurate characteristic. One way of achieving this mix could be based on gender.

The findings can further have implications on the recruitment process where it ought to be of outmost interest for the auditing firm to be aware of what specific characteristics they are looking for, and then try to attract this.

It is probably not possible for the individual auditor to have all the important characteristics. Even though skills can be developed by education and training, one could assume that it still is hard to "be good at everything". Hence, when it comes to conducting high quality audits the results in this study support auditors working in teams consisting of individual auditors with different distinguished characteristics.

To conclude, the paper does not emphasise one sex in relation to another, it attempts instead to distinguish characteristics that, through a gender lens, are more or less important for different stages in the auditing process, something that also is supported in the study. 


\section{REFERENCES}

Acker, J. (1990). Hierarchies, Jobs, Bodies: A theory of gendered organizations. Gender and Society, Vol. 4, No. 2, pp. 139-158.

Akerlof, G. (1970). The Market for"Lemons": Quality Uncertainty and the Market Mechanism. Quarterly Journal of Economics, August 1970, pp. 488-500.

Anderson-Gough, F., Grey, C. \& Robson, K. (1998). Making Up Accountants. The organizational a professional socialization of trainee chartered accountants. Aldershot, Ashgate/ICAEW.

Anderson-Gough, F., Grey, C. \& Robson, K. (2005). "Helping them to forget...": the organizational embedding of gender relations in public audit firms. Accounting, Organizations and Society, Vol. 30, No. 5, pp. 469-491.

Arfken, D.E., Bellar, S.L. \& Helms, M.M. (2004). The ultimate glass ceiling revisited: the presence of women on corporate boards. Journal of Business Ethics, Vol. 50, No. 2, pp. 177186.

Armstrong, M. (2006). A Handbook of Human Resource Management Practice. (10 ${ }^{\text {th }}$ ed). London: Kogan Page.

Bertrand, M. \& Hallock, K. (2001). The gender gap in top corporate jobs. Industrial and Labor Relations Review, Vol. 55, No. 1, pp. 3-21.

Bowlin, W. F. \& Renner, C. J. (2007). Assessing gender and top-management-team pay in the S\&P Mid-Cap and Small-Cap companies using data envelopment analysis. European Journal of Operational Research, Vol. 185, No. 1, pp. 430-437.

Brante, T. (1988). Sociological Approaches to the Professions. Acta Sociologica, Vol. 31, No. 2, pp. 119-142.

Brody, R. G., Golen, S. P. \& Reckers, P. M. J. (1998). An Empirical Investigation of the Interface between Internal and External Auditors. Accounting and Business Research, Vol. 28, No. 3, pp. 160-171.

Carr-Saunders, A. M. \& Wilson, P. A. (1933). The Professions. Oxford, England: Oxford University Press.

Cho, S. \& Lew, A. Y. (2000). Analytical review applications among large audit firms in Hong Kong. Managerial Auditing Journal, Vol. 15, No. 8, pp. 431-438.

Collin, S-O., Jonnergård, K., Qvick, P., Silfverberg, B. \& Zabit, S. (2007). Gendered Career Rein: A Gender Analysis of the Certification Process of Auditors in Sweden. International Journal of Auditing, Vol. 11, No. 1, pp. 17-39.

Covaleski, M. A., Dirsmith, M, W., Heian, J. B. \& Samuel, S. (1998). The calculated and the avowed: techniques of discipline and struggles over identity in big six public accounting firms. Administrative Science Quarterly, Vol. 43, No. 2, pp. 293-327. 
Daily, C. M. \& Dalton, D. R. (2003). Women in the boardroom: A business imperative. The Journal of Business Strategy, Vol. 24, No. 5, pp. 8-9.

Dalton, D. R. \& Kesner, I. F. (1993). Cracks in the glass: the silent competence of women. Business Horizons, Vol. 36, No. 2, pp. 6-12.

Davies, A. \& Thomas, R. (2002). Gendering and gender in public service organizations changing professional identities under new public management. Public Management Review, Vol. 4, No. 4, pp. 461-484.

Dirsmith, M. \& Covaleski, M. (1985). Informal Communications, Nonformal Communications, and Mentoring in Public Accounting. Accounting, Organizations and Society, pp. 149-169.

Dirsmith, M. W. \& Haskins, M. E. (1991). Inherent Risk Assessment and Audit Firm Technology: A Contrast in the World Theories. Accounting, Organizations and Society, Vol. 16, No. 1, pp. 61-90.

Duggal Sharma, A. \& Schischke, S. (2007). Könens komparativa fördelar I revisonsprocessen. Bachelor thesis. Kristinstad University College.

Elg. U., Jonnergård, K. \& Månsson, J. (2006). The effects of gender factors on organizational inclusion and structural position. Paper presented at EAA annual conference in Dublin.

Ely, R. J. (1995). The power in demography: Women's social constructions of gender identity at work. The Academy of Management Journal, Vol. 38, No. 3, pp. 589-634.

Financial Reporting Council. (2006). Promoting Audit Quality. Discussion paper. November 2006.

Flint, D. (1988). Philosophy and principles of auditing. An introduction. London: Macmillan.

Fogharty, T. J., Parker, L. M. \& Robsinson, T. (1998). Where the rubber meets the road: performace evaluation and gender in large public accounting organizations. Women in Management Review, Vol. 13, No. 8, pp. 299-310.

Grey, C. (1998). On being a professional in a "big six" firm. Accounting, Organizations and Society, Vol. 23, No. 5/6, pp 569-587.

Hayes, R., Dassen, R., Schilder, A. \& Wallage, P. (2005). Principles of Auditing. An Introduction to International Standards on Auditing. (2 ${ }^{\text {nd }}$ ed.). Harlow: Pearson Education Limited.

Huse, M. (2007). Boards, Governance and Value Creation. New York: Cambridge University Press.

Hayes, J., Allinson, C. W. \& Armstrong, S. J. (2004). Intuition, women managers and gendered stereotypes. Personnel Review, Vol. 33, No. 4, pp. 403-417. 
ICAEW. (2007). Information for better markets. Reporting with integrity. Institute of Chartered Accountants in England \& Wales. April 2007.

Kanter, R. (1977), Men and Women of the Corporation. New York: Basic Books.

Kirkham, L. (1992a). Integrating herstory and history in accountancy. Accounting, Organizations and Society, Vol. 17, No. 3/4, pp. 287-297.

Kirkham, L. M. (1992b). Putting auditing practices in context: deciphering the message in auditor response to selected environmental cues. Critical Perspectives on Accounting, Vol. 3, No. 3, pp. 291-314.

Kirkham, L. \& Loft, A. (1993). Gender and the construction of the professional accountant. Accounting, Organizations and Society, Vol. 18, No. 6, pp. 507-558.

Larsson, M. S. (1977). The Rise of Professionalism. A Sociological Analysis. London. University of California press.

Lehman, C. (1990). The importance of being earnest: Gender conflicts in accounting. Advances in Public Interest Accounting, Vol. 3, pp. 137-157.

Lehman, C. R. (1992). "Herstory" in accounting: The first eighty years. Accounting, Organizations and Society, Vol. 17, No. 3/4, pp. 261-285.

Lowe, D. J., Reckers, P. M. J. \& Sanders, D. (2001). The influence of gender, ethnicity, and individual differences on perceptions of career progression in public accounting. International Journal of Auditing, V1. 5, pp. 53-71.

Markland, B. (2007). Historien om historien. Balans, No. 6-7, pp. 33-35.

Marsden, P. V. \& Campbell, K. E. (1990). Recruitment and selection processes: The organizational side of job search. In R. Brieger (Ed.), Social mobility and social structure: 5979. New York: Cambridge University Press.

Mautz, R. K. \& Sharaf, H. A. (1961). The Philosophy of Auditing. Sarasota, Florida: American Accounting Assocation.

Mills, A. J. (1992). Organization, Gender and Culture. In A. J. Mills \& P. Tancred (Eds.), Gendering and Organizational Analysis. London: Sage.

Moir, A. \& Jessel, D. (1989). Brain Sex - The real difference between men and women. London: Joseph.

Mohan, N. \& Ruggiero, J. (2003). Compensation differences between male and female CEOs for publicly traded firms: A nonparametric analysis. Journal of the Operational Research Society, Vol. 54, pp. 1242-1248.

Moore, G. (1990). Structural determinants of men's and women's personal networks. American Sociological Review, Vol. 55, pp. 726-735. 
Morris, D. (1998). Det motsatta könet: kvinnor och män-skillnader, likheter, möjligheter. Stockholm: B. Wahlström

Morrison, A. M. \& von Glinow, M. A. (1990). Women and minorities in management. American Psychologist, Vol. 45, No. 2, pp. 200-208.

Oshagbemi, T. \& Gill, R. (2003). Gender differences and similarities in the leadhership styles and behaviours of UK managers. Women in Management Review, Vol. 18, No. 2, pp 288-298.

Pease, A. \& Pease, B. (2006). Why men don't listen and women can't read maps. Orion Publishing Co.

Plowman, P. (2000). Organisational change from two perspectives: gender and organisational development. Development in Practice, Vol. 10, No. 2, pp. 189-203.

Porter, B., Simon, J. \& Hatherly, D. (2006). Principles of External Auditing. (2nd ed.). Chichester: John Wiley \& Sons Ltd.

Pounder, J. S. \& Coleman, M. (2002). Women - better leaders than men? In general and educational management it still all depends. Leadership \& Organization Development Journal, Vol. 23, No. 3, pp. 122-133.

Rigg, C. \& Sparrow, J. (1994). Gender, diversity and working styles. Women in Management Review, Vol. 9, No. 1, pp. 9-16.

Shields, S. A. (2007). Passionate men, emotional women: Psychology constructs gender difference in the late 19th century. History of Psychology, Vol. 10, No. 2, pp. 92-110.

Stainton, R. W. \& Stainton, R. R. (2002). Genuspsykologi: kön och sexualitet. Lund: Studentlitteratur.

Tharenou, P. (2001). Going up? Do traits and informal social processes predict advancing in management? Academy of Management Journal, Vol. 44, No. 5, pp. 1005-1017.

Trinidad, C. \& Normore, A. H. (2005). Leadership and gender: a dangerous liaison? Leadership \& Organization Development Journal, Vol. 26, No. 7-8, pp. 574-590.

Tsui, A. S \& O’Reilly III, C. A. (1989). Beyond simple demographic effects: the importance of relational demography on superior-subordinate dyads. Academy of Management Journal, Vol. 32, No. 2, pp. 402-423.

Valentine, S. R. \& Rittensburg, T. L. (2007). The ethical decision making of men and women executives in international business situations. Journal of Business Ethics, Vol. 71, No. 2, pp. $125-134$.

Verheul I., Uhlaner, L. \& Thurik, R. (2005). Business accomplishments, gender and entrepreneurial self-image. Journal of Business Venturing, Vol. 20, No. 4, pp. 483-518.

Woolf, E. (1997). Auditing Today. (6 ${ }^{\text {th }}$ ed.). Harlow: Pearson Education Limited. 